Perbandingan Kebugaran Jasmani....(Rury Rizhardi)

\title{
PERBANDINGAN KEBUGARAN JASMANI ANTARA SEKOLAH DI PERKOTAAN DAN DI PEDESAAN STUDI KASUS DI SMA NEGERI 5 PALEMBANG DAN SMA NEGERI 2 BANYUASIN 2
}

\author{
Oleh: Rury Rizhardi \\ (Dosen Universitas PGRI Palembang) \\ Email: rury_rizhardi@yahoo.com
}

\begin{abstract}
Abstrak
Penelitian bertujuan untuk mengetahui perbedaan kebugaran jasmani peserta didik kelas X yang bersekolah di SMA Negeri 5 Palembang dan SMA Negeri 2 Banyuasin 2. Penelitian ini merupakan penelitian komperatif yang menggunakan metode survei dengan teknik pengambilan data berupa tes. Populasi dari penelitian ini berjumlah 30 peserta didik. Pengumpulan data menggunakan tes dengan instrumen Tes Kebugaran Jasmani Indonesia (TKJI) usia 16-19 tahun dari Depdiknas. Teknik analisis data menggunakan uji P dengan mempersentasikan hasil tes yang dilakukan. Berdasarkan analisis hasil penelitian dan pembahasan yang diperoleh rata-rata nilai kebugaran jasmani SMA Negeri 5 Palembang sebesar 12,33, dan SMA Negeri 2 Banyuasin 2 16,8, hasil analisis data menunjukkan terdapat perbedaan kebugaran jasmani peserta didik kelas X SMA Negeri 5 Palembang dan SMA Negeri 2 Banyuasin 2. Tingkat kebugaran SMA Negeri 2 Banyuasin 2 lebih bagus ketimbang SMA Negeri 5 Palembang.
\end{abstract}

Kata kunci: Kebugaran Jasmani, Sekolah di Perkotaan, Sekolah di Pedesaan

\section{COMPARISON OF THE FUTURE OF THE COLLABORATION BETWEEN SCHOOLS IN URBAN AND AND THE RURAL CASE STUDY IN PALEMBANG 5 STATE HIGH SCHOOL AND BANYUASIN 2 STATE HIGH SCHOOL 2}

\begin{abstract}
The study aims to determine the differences in physical fitness of class $X$ students who study at Palembang State High School 5 and Banyuasin 2 High School 2. This research is a comparative research that uses survey methods with data collection techniques in the form of tests. The population of this study amounted to 30 students. Data collection uses tests with instruments of the Indonesian Physical Fitness Test (TKJI) aged 16-19 years from the Ministry of National Education. The data analysis technique uses the $P$ test by presenting the results of the tests performed. Based on the analysis of the results of the research and discussion which obtained the average physical fitness value of Palembang State Senior High School at 12.33, and State High School 2 Banyuasin 2 16.8, the results of data analysis showed that there was a difference in physical fitness of class $X$ students of Palembang State High School 5 and SMA 2 Banyuasin 2. The fitness level of Banyuasin 2 High School 2 is better than Palembang State High School 5.
\end{abstract}

Keywords: Physical Fitness, Schools in Urban, Schools Rural Areas 
Wahana Didaktika Vol. 17 No. 3 September 2019 : 297-304

\section{A. PENDAHULUAN}

Pada era globalisasi seperti sekarang ini kemajuan teknologi, komunikasi, dan transportasi berkembang dengan sangat pesat. Kebanyakan orang cenderung memilih untuk bermain gadget dari pada melakukan aktivitas fisik. Kurang melakukan aktifitas fisik akan mempengaruhi kebugaran jasmani, sehingga dalam melakukan aktifitas sehari-hari menjadi tidak maksimal. Semua bentuk kegiatan manusia selalu memerlukan dukungan fisik, masalah kemampuan fisik merupakan faktor dasar bagi setiap aktifitas manusia. Maka untuk melakukan setiap aktifitas sehari-hari, minimal harus mempunyai kemampuan fisik yang selalu mendukung aktifitas tersebut. Pada saat ini manusia menyadari betapa pentingnya melakukan aktifitas olahraga karena adanya berolahraga kita dapat meningkatkan dan menjaga kesehatan jasmani dan rohani. Salah satunya adalah mewujudkan manusia indonesia seutuhnya melalui pendidikan jasmani dan olahraga.

Semakin sering manusia berolahraga maka kesehatan tubuhnya akan semakin terjaga. Manusia yang sehat merupakan sumber daya yang dibutuhkan dalam melaksanakan pekerjaan atau rutinitas sehari-hari dengan fisik yang prima, tanpa mengalami kelelahan yang berat setelah melaksanakan aktifitas tersebut serta memiliki kemampuan fisik yang baik untuk melakukan pekerjaan tambahan lainya. Dalam penelitian ini penulis hanya ingin mengetahui kebugaran jasmani dari masingmasing sekolah, Bagaimanakah perbandingan atau perbedaan sekolah yang berada di perkotaan dan di pedesaan dengan asupan gizi yang berbeda, tingakat aktivitas/ berolahraga yang berbeda dan letak geografis yang juga berbeda.

Berdasarkan Pemaparan di atas, penulis latar bekang tersebut, penulis menganggap penting membahas masalah ini dalam penelitian dengan harapan hasil penelitian ini dapat bermanfaat bagi seluruh siswa dan siwa SMA Negeri 5 Palembang dan SMA Negeri 2 Banyuasin 2, sebagai acuan untuk siswa dan siswa sehat dan bugar dalam menjalankan aktifitas sehari-hari. Oleh karena itu, penulis ingin meneliti lebih lanjut tentang kebugaran jasmani siswa dan siswi SMA Negeri 5 Palembang dan SMA Negeri 2 Banyuasin. Jadi peneliti tertarik untuk meneliti Perbandingan Kebugaran Jasmani Antara Sekolah di Perkotaan dan Sekolah di Perdesaan Studi Kasus di SMA Negeri 5 Palembang dan SMA Negeri 2 Banyuasin. 
Perbandingan Kebugaran Jasmani....(Rury Rizhardi)

Meskipun kata kebugaran dan kebugaran selalu dipakai secara bergantian namun secara terminologi keduanya mengandung makna yang sama, dalam bahasa lain juga dikenal dengan fitness. Salah satu definisi kebugaran jasmani atau fitnessmenurut pendapat President's Council On Physical Fitness and sport, adalah "kemampuan untuk melakukan kegiatan sehari-hari dengan penuh vitalitas dan kewaspadaan tanpa mengalami kelelahan yang berarti, dan masih cukup energi untuk bersantai pada waktu luang dan menghadapi hal-hal yang sifatnya darurat" (Widiastuti, 2015:13). Berdasarkan pendapat Faqih dan Hartati (2017) kebugaran jasmani merupakan "ukuran kemampuan kerja manusia yang sangat berperan dalam menunjang unjuk kerja fisik (antara lain prestasi kerja, prestasi olahraga dan prestasi belajar)".

Kebugaran jasmani seseorang tidak hanya di capai dengan aktivitas fisik yang dilakukan seseorang, tetapi kebugaran jasmnai mempunyai beberapa aspek agar semua komponen kebugaran jasmani terpenuhi. Seseorang yang mempunyai kebugaran jasmani yang baik pasti akan mempunyai kualitas kesehatan yang baik dan kecerdasan emosional yang stabil. Adapun komponen kebugaran jasmani menurut Arifin (2018:24-25) adalah sebagai berikut:
a. Daya tahan (endurance)
b. Komposisi tubuh
c. Kecepatan (speed)
d. Keseimbangan (balance)
e. Kelincahan (agility)
f. Koordinasi (coordination)
g. Daya (power)

Pada dasarnya kebugaran jasmani dipengaruhi oleh dua faktornutma yang terbagi menjadi faktor internal dan faktor eksternal. Faktor internal merupakan faktor yang sudah melekat dan menetap pada seorang individu, seperti faktor genetik, usia, maupun jenis kelamin. Sedangkan faktor eksternal ini merupakan faktor yang terdapat atau diperoleh dari luar seperti latihan, aktivitas fisik, gaya hidup, status gizi, dan lain-lain. Pentingnya kebugaran jasmani bagi anak usia sekolah antara lain meningkatkan kemampuan organ tubuh, sosial emosional, sportifitas dan semangat 
kompetisi. Beberapa peneliti juga menyebutkan bahwa kebugaran jasmani memiliki korelasi positif dengan prestasi akademis.

Pengertian tes secara umum adalah "suatu alat pengumpul data dan sebagai dasar penilaian dalam proses pendidikan" (Widiastuti, 2015:1). Fenanlampir (2015:1) Tes adalah "instrumen atau alat yang digunakan untuk memperoleh informasi tentang individu dan subjek". Pengukuran adalah "proses pengumpulan data atau informasi yang dilakukan secara objektif" (Fenanlampir dan Faruq, 2015:2). Evaluasi adalah "proses penentuan nilai atau harga dari data yang terkumpul” (Fenanlampir dan Faruq, 2015:2).

\section{B. METODOLOGI PENELITIAN}

Variabel dalam penelitian ini adalah kebugaran jasmani peseta didik kelas $\mathrm{X}$ SMA Negeri 5 Palembang dan SMA Negeri 2 Banyuasin 2 tahun ajaran 2018/2019. Metode yang digunakan dalam penelitian ini adalah metode survei. Pada penelitian ini akan membandingkan atau mencari perbedaan tingkat kebugaran jasmani peserta didik yang bersekolah di SMA Negeri 5 Palembang dan SMA Negeri 2 Banyuasin 2.

Dalam penelitian ini terdapat dua variabel terikat $(\mathrm{X})$ dan bebas $(\mathrm{Y})$ yaitu:

a. Variabel bebas (X): Kebugaran Jasmani.

b. Variabel terikat (Y): Peserta didik putra dan putri SMA Negeri 5 Palembang dan SMA Negeri 2 Banyuasin 2.

Tingkat kebugaran jasmani peserta didik akan diukur menggunakan tes kebugaran jasmani indonesia (TKJI) untuk remaja usia 16-19 tahun (Widiastuti, 2015:45). Komponen TKJI terdiri dari: untuk putra (Lari cepat 60 meter, gantung angkat tubuh 60 detik, baring duduk 60 detik, loncat tegak, lari 1200 meter). Untuk putri (Lari cepat 60 meter, gantung angkat tubuh 60 detik, baring duduk 60 detik, loncat tegak, lari 1000 meter). Penelitian ini di laksanakan pada jam pelajaran olahraga di lapangan/halaman sekolah SMA Negeri 5 Palembang dan SMA Negeri 2 Banyuasin 2.

Penelitian ini tergolong penelitian Deskriptif kuantitatif tentang tingkat kebugaran jasmani peserta didik kelas X SMA Negeri 5 Palembang dan SMA Negeri 2 Banyuasin 2 tahun ajaran 2018/2019. Populasi dalam penelitian ini adalah 332 
Perbandingan Kebugaran Jasmani....(Rury Rizhardi)

peserta didik kelas X yang bersekolah di SMA Negeri 5 Palembang dan SMA Negeri 2 Banyuasin 2. Seluruh populasi tersebut terdiri dari peserta didik putra dan putri. Analisis dalam penelitian ini dilakukan dengan cara stastistik deskriptif kuantitatif.

\section{HASIL PENELITIAN DAN PEMBAHASAN}

\section{Tingkat Kebugaran Jasmani Kelas X SMA Negeri 5 Palembang Tahun Ajaran 2018/2019.}

Rangkaian tes kebugaran jasmani yang dilaksanakan antara lain: lari 60 meter, gantung angkat tubuh/gantung siku tekuk, baring duduk 60 detik, loncat tegak dan lari 1000/1200 meter.Berdasarkan penelitian yang dilakukan pada tanggal 18 juni 2019 di halaman dan DAM belakang sekolah SMA Negeri 5 Palembang diketahui hasil Tes Kebugaran Jasmani Peserta didik adalah sebagai berikut

Berdasarkan data di atas dapat dijelaskan bahwa secara keseluruhan tingkat kebugaran jasmani SMA Negeri 5 Palembang Tahun 2018/2019, terdapat 0 peserta didik $(0,00 \%)$ dalam kategori baik sekali, 1 peserta didik $(6,66 \%)$ dalam kategori baik, 5 peserta didik $(33,33 \%)$ dalam kategori sedang, 7 peseta didik $(46,66 \%)$ dalam kategori kurang, dan 2 peserta didik $(13,33 \%)$ dalam kategori kurang sekali. Frekuensi terbanyak terdapat pada kategori Kurang, sehingga dapat disimpulkan bahwa tingkat kebugaran jasmnai peserta didik kelas X SMA Negeri 5 Palembang Tahun 2018/2019 secara keseluruhan sebagian besar Kurang. Apabila digambarkan dalam diagram batang, maka gambar diagram batang tingkat kebugaran peserta didik kelas X SMA Negeri 5 Palembang adalah sebagai berikut:

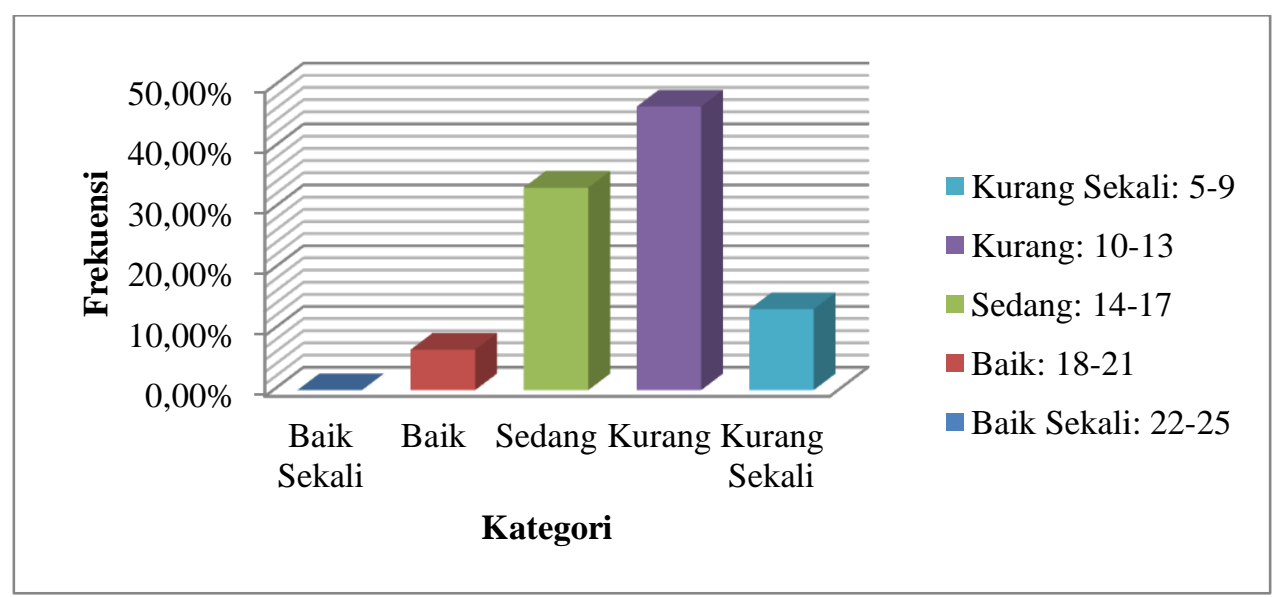

Gambar 1. Diagram Tingkat Kebugaran SMA Negeri 5 Palembang 


\section{Tingkat Kebugaran Jasmani Kelas X SMA Negeri 2Banyuasin 2Tahun Ajaran 2018/2019.}

Berdasarkan penelitian yang dilakukan pada tanggal 20-12 Juni 2019 di halaman sekolah dan jalan utama desa Jati Sari. Berdasarkan data di atas dapat dijelaskan bahwa secara keseluruhan tingkat kebugaran jasmani SMA Negeri 2 Banyuasin 2 Tahun 2018/2019, terdapat 0 peserta didik (0,00\%) dalam kategori baik sekali, 7 peserta didik $(46,66 \%)$ dalam kategori baik, 4 peserta didik $(26,66 \%)$ dalam kategori sedang, 4 peseta didik $(26,66 \%)$ dalam kategori kurang, dan 0 peserta didik $(0,00)$ dalam kategori kurang sekali. Frekuensi terbanyak terdapat pada kategori Baik, sehingga dapat disimpulkan bahwa tingkat kebugaran jasmnai peserta didik kelas X SMA Negeri 2 Banyuasin 2 Tahun 2018/2019 secara keseluruhan sebagian besar Baik.Apabila di gambarkan dalam diagram batang, maka gambar diagram batang tingkat kebugaran peserta didik kelas X SMA Negeri 2 Banyuasin 2 adalah sebagai berikut:

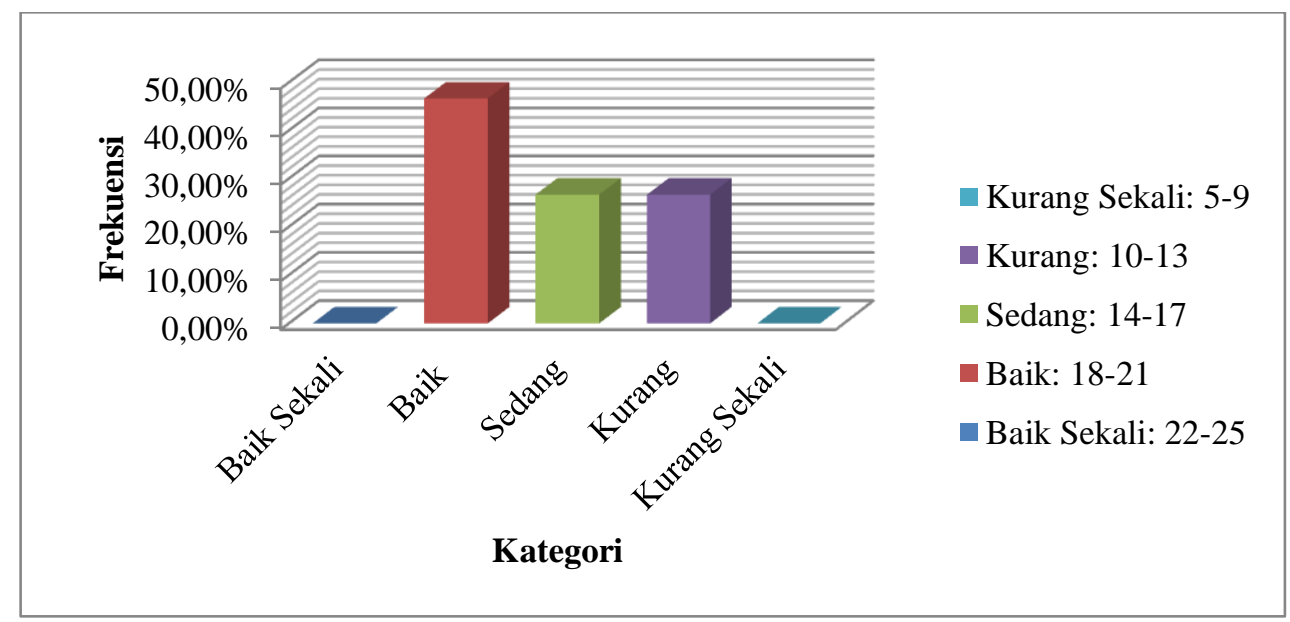

Gambar 2. Diagram Tingkat Kebugaran SMA Negeri 2 Banyuasin 2

Kebugaran jasmani merupakan salah satu faktor yang berpengaruh bagi perkembangan di sekolah. Pada anak usia sekolah, dibutuhkan tingkat kebugaran jasmani yang baik, sehingga mendukung bagi perkembangan siswa dalam melakukan kegiatan apapun di sekolah. Komponen kebugaran jasmani meliputi: kemampuan daya tahan dan paru, kekuatan otot, daya tahan otot, fleksibilitas, dan komposisi tubuh terkait dengan peningkatan kesehatan. Pada penelitian ini kebugaran jasmani 
diartikan sebagai gambaran siswa kelas X SMA Negeri 5 Palembang dan SMA Negeri 2 Banyuasin 2 tahun ajaran 2018/2019 dalam melakukan aktivitas jasmani dan terlihat saat melakukan aktivitas jasmani tidak adanya kelelahan yang berlebih, sehingga siswa masih bisa menikmati waktu luangnya.

Kebugaran jasmani siswa kelas SMA Negeri 5 Palembang dan SMA Negeri 2 Banyuasin 2 di ukur dengan menggunakan Tes Kebugaran Jasmani Indonesia (TKJI) untuk anak usia 16-19 tahun. Tes ini terdiri dari 5 item tes, yaitu: tes lari 60 meter, gatung siku tekuk, baring duduk, loncat tegak, dan lari 1200/1000 meter.

\section{SIMPULAN}

Analisis data menunjukkan bahwa terdapat perbedaan Kebugaran Jasmani Peserta didik Kelas X yang bersekolah di Kota SMA Negeri 5 Palembang dan di Desa SMA Negeri 2 Banyuasin 2 Tahun ajaran 2018/2019. Kebugaran jasmani peserta didik kelas X SMA Negeri 2 Banyuasin 2 lebih baik dari peserta didik kelas X SMA Negeri 5 Palembang. Berdasarkan deskripsi dan penelitian menunjukkan bahwa kebugaran jasmani peserta didik kelas X SMA Negeri 2 Banyuasin 2 sebagian besar peserta didik mempunyai tingkat kebugaran jasmani pada kategori baik, sedang dan kurang, dengan persentase 46,66\%, 26,66\%, dan 26,66\%.

Sedangkan pada peserta didik kelas X SMA Negeri 5 Palembang sebagian besar masuk pada kategori kurang dan sedang, yaitu dengan pesentase 46,66\% dan 33,33\%. Rata-rata kebugaran jasmani SMA Negeri 5 Palembang sebesar 12,33 dan SMA Negeri 2 Banyuasin 2 sebesar 16,18. Oleh karena itu dapat di simpulkan bahwa hipotesis penelitian dari penelitian ini menunjukkan terdapat perbedaan yang signifikan antara kebugaran jasmani peserta didik kelas X SMA Negeri 2 Banyuasin 2 dan SMA Negeri 5 Palembang. 


\section{DAFTAR PUSTAKA}

Arifin, Z. (2018). Pengaruh Latihan senam Kebugaran Jasmani (SKJ) Terhadap Tingkat Kebugaran Siswa Kelas V Di Min Donomulyo Kabupaten Malang. AL-Mudarris , 24-27.

Faqih, S. C. (2017). Survei Tingkat Kebugaran Jasmani Siswa Kelas IV dan V Sekolah Dasar Se-Gugus Selatan Kecamatan Plumpung Kabupaten Tuban. Jurnal Pendidikan Olahraga dan Kesehatan , 386-387.

Faruq, F. d. (2017). Tes dan Pengukuran dalam Olahraga. Yogyakarta: Andi Offset.

Widiastuti. (2015). Tes dan Pengukuran Olahraga. Jakarta: PT RajaGrafindo. 